\title{
Variation in the Diet of Foxes in Scotland
}

\author{
H. H. KOLB \& R. HEWSON
}

\begin{abstract}
Kolb H.H. \& Hewson R., 1979: Variation in the diet of foxes in Scotland. Acta theriol., 24, 6: 69-83 [With 8 Tables, 2 Figs. \& 3 Appendixes] Differences in the diet of foxes between regions of Scotland, and changes with season and from year to year are described from stomach and scat contents. Rabbits and game birds are the main prey in North-east Scotland. Short-tailed voles form the main prey during the autumn and winter in the West, with sheep and lambs being most important in the spring. In the North-west deer is more frequent in the diet. Voles and rabbits vary in their occurrence in stomachs and scats depending upon population fluctuations. In the West in spring, lamb remains form from 35 to $45 \%$ of the diet and this is discussed in relation to the impact of the fox on agriculture.

[Dept. Agriculture and Fisheries, c/o Inst. Terrestr. Ecol., Blackhall Res. Station, Banchory AB3 3PS, Scotland]
\end{abstract}

\section{INTRODUCTION}

The fox (Vulpes vulpes L.) is an important predator in Scotland and is widely regarded as a pest. Its chief economic depredations are on lambs and game birds, and to a lesser extent poultry. Large numbers of foxes are killed each year in an attempt to reduce losses to agricultural and sporting interests. However, no attempt has been made until now to quantify such losses in Scotland, or to examine the effect of control methods on fox populations as opposed to natural limiting and regulatory factors. The information given in this paper forms part of a general study of fox biology in relation to farming interests in Scotland.

Whereas much work has been done on foxes in other parts of the world none is directly applicable to Scottish conditions. Much of Scotland consists of wet hill ground where the main land uses are hill sheep farming, deer stalking and forestry. Yet within relatively short distances of these areas there are predominantly dry moorlands managed for grouse, and extensive areas of mixed agriculture; foxes are found in all these regions ( $\mathrm{H} \mathrm{e} \mathrm{w} \mathrm{s} \mathrm{on} \mathrm{\&} \mathrm{Kol} \mathrm{b,} \mathrm{1973).}$

Some information on the diet of Scottish foxes has already been published. Southern \& Watson (1941) looked at the stomach contents of seven foxes from Scotland, and Lever (1959) at the contents of 29 stomachs and 13 scats from scattered areas. The only 
complete work has been that of Lockie $(1956,1964)$. The first of these studies (1956) was concerned with short term changes in the diet due to myxomatosis in the rabbit population, and was based on small samples which came chiefly from southern Scotland. The second was a comparison of the diet of eagles and foxes in Wester Ross.

A general knowledge of an animal's diet is a necessary preliminary to any study of populations since food is considered to be one of the most important ultimate factors in the limitation of density (W a t s o n, 1970). In addition, the food preferences of a vertebrate pest species often determine the animal's impact on agriculture. Answers to the following questions were sought in this study.

1. How much do species of economic importance feature in the diet in different regions, and during different seasons of the year?

2. How much does the diet vary between regions?

3. How much variation is there in the diet from year to year in each region, and how can this be related to the availability of different foods?

\section{STUDY AREAS}

Three regions of Scotland were studied. The two main ones were the Northeast (areas 1-4) and Argyll and West Perth (areas 5 \& 6, Fig. 1). For brevity areas $5 \& 6$ will be referred to as the West and area 7 as Lochaber. The Northeast is predominantly farmland near sea, with a greater proportion of forested ground inland, rising up to the foothills of the Grampian Mountains which are mainly moorland (especially area 3). The West is mostly hill land with sheep farming and forestry ts the predominant land use. Lochaber is wilder and more mountainous with most of the open ground as deer forest, and sheep farming in the glens. The Lochaber region was not large enough to subdivide but the others were divided arbitrarily into areas for subsampling (Fig. 1).

\section{MATERIAL}

Fox carcasses were obtained from forestry rangers, gamekeepers and shepherds. All the animals had been killed during the normal course of fox control by snaring and shooting. The places from which foxes were obtained are shown in Fig. 1.

Fox scats were collected on tracks from October to April each year (the only period of the year when they can consistently be found). In the Northeast all the tracks were in forest, but in the West scats came from one area of forest and another of open hill (Fig.1). The same tracks in the North-east and the open hill area of Argyll were cleared once every two months, but scats from the forest area in the West were collected less systematically by Forestry Commission personnel.

During the study 858 stomachs from adult foxes were examined. Of these, 445 had contents $(52 \%)$. In North-east Scotland foxes were obtained over four years, in the West over three and Lochaber over two. In total, 1819 fox scats were collected and analysed over five years. 


\section{METHODS}

\subsection{Treatment of Material}

Stomachs were removed from foxes and the contents taken out and weighed wet. The material was then washed in a sieve and the constituents identified by comparison with a reference collection of potential prey items and from the information given in $\mathrm{Day}$ (1966) and $\mathrm{W} i \mathrm{ldm}$ an (1954). The percentage volume of each component was assessed visually.

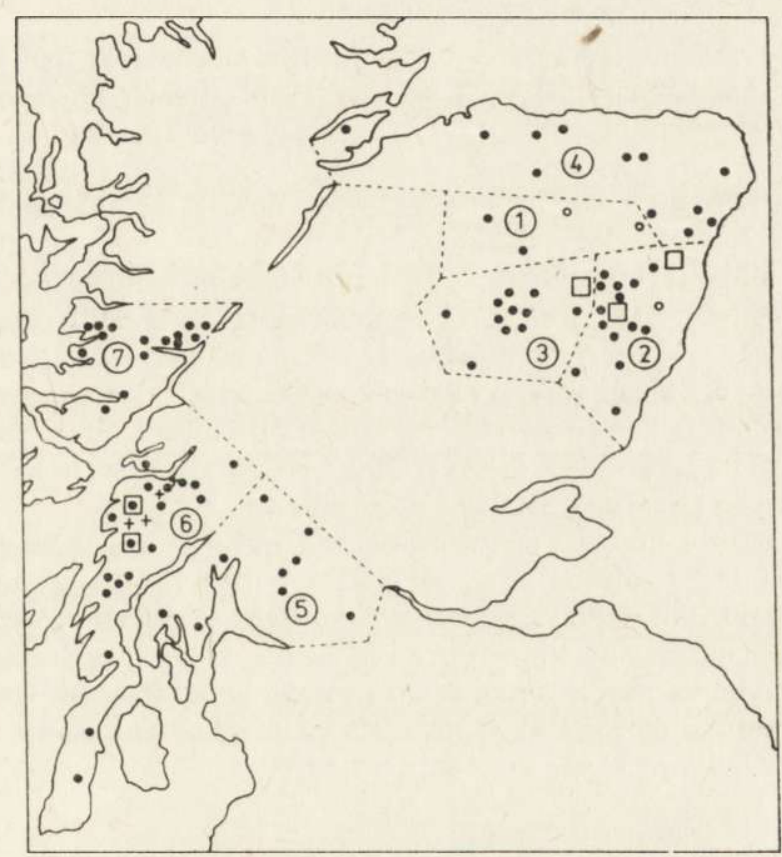

Fig. 1. Areas in Scotland from which material was obtained.

Circles show places where foxes were killed (open circles are those forests used for the calculation of data for Fig. 2); squares are areas where fox scats were collected; crosses are Microtus trapping sites.

Scats were dried and weighed, and then broken up in water in a food mixer. Prey items were identified in the same way as for stomach contents except that more reliance had to be placed on microscopical rather than gross features.

\subsection{Quantitative Analysis}

Several methods of analysing carnivore diets are available and the relative merits of some of these have been discussed by Englund (1965). Recent workers on the food of foxes who have concentrated on scat analysis have tended to prefer L ockie's (1959) method of estimating the weight of consumed material through conversion factors for digestibility. 
However frequency analysis was used in the present study for the following reasons:

1. Both stomach and scat cantents were analysed. No simple correction factors can be calculated for food from stomach contents because the degree of digestion is indeterminable. Stomach and scat analyses can be directly compared only on the frequency with which items occur.

2. The study concentrated more on differences between areas, seasons and years than on the relative biomass of different food items eaten within one area. Comparison of the frequency of the same type of food in different places and years is not affected by considerations of digestibility and allows relatively straightforward statistical analysis.

The chief problem that arises from frequency analysis is that small items in in stomachs and scats have the same 'weight' as big items. Therefore to make the frequency analyses more meaningful occurrences were recorded as 'main' (making up $50 \%$ or more of the volume) and 'total' occurrence of an item). As a check on these two methods of measurement actual weight analyses were also worked out for stomach and scat contents (Appendices I and II). In all samples these were more highly correlated with main contents frequencies than with total frequencies (Appendix III). The differences between the weight results for stomach and scat contents are consistent with the known differential digestibilities of the foods (Lockie, 1959). These results suggest that, percentage main stomach 'contents' is a good indicator of the relative bulk intake of a food in an area, provided account is taken of small volumes of material, such as insect remains, which rarely appear as main items in a stomach.

The definitions of a number of terms used in the text are: Percentage frequency of occurrence - the number of times an item occurred in a sample expressed as a percentage of the total number of stomachs or scats. Percentage relative frequency - the number of times an item occurred as a percentage of the total cccurrence of all items in the sample. Percentage weight - the weight of all the remains of a category of food in a sample as a percentage of the total weight of material in the sample of stomachs (wet) or scats (dry).

\section{RESULTS}

\subsection{Details of Prey}

\section{A. Rabbits and Hares}

Because of the difficulties of distinction, for general purposes these have been lumped into the category "Lagomorph". However a positive identification could often be made from stomach contents. In the West, of eight such cases, all were of rabbit (Oryctolagus cuniculus). In the North-east of 52 positive indentifications, 41 were of rabbit, eight of mountain hare (Lepus timidus) and three of brown hare (Lepus capensis). Of the mountain hare occurrences seven were in area 3 , where rabbit only occurred twice. All stages of rabbit development were found in stomachs from the North-east, from new-born nestlings to adult animals. 


\section{B. Small Mammals}

These are readily identifiable from tooth and hair structure and nearly all occurrences could be assigned to species. Of all these the single most important in the diet was the short-tailed vole (Microtus agrestis) (Table 1). This was particularly so in the West and Lochaber but in the North-east a much greater variety of rodent and insectivore species was eaten.

\section{Table 1}

The presence of species of small mammals in the stomachs of adult foxes as a percentage of the total occurrence of small mammals in stomachs in an area.

\begin{tabular}{lcccc}
\hline Number of stomachs with small mammals & $\begin{array}{c}\text { North-east } \\
67\end{array}$ & $\begin{array}{c}\text { West } \\
104\end{array}$ & $\begin{array}{c}\text { Lochaber } \\
19\end{array}$ \\
\hline Microtus agrestis & 64 & 86 & 84 \\
Apodemus sylvaticus & 17 & 6 & - \\
Clethrionomys glareolus & 2 & 2 & - \\
Rattus norvegicus & 3 & - & - \\
Arvicola terrestris & 2 & - & - \\
Sorex sp. & 6 & 3 & - \\
Talpa europea & -6 & 2 & 11 \\
Unidentifiable & 6 & 2 &
\end{tabular}

C. Sheep and Lamb

In the general comparisons these have been lumped together in the category ,sheep'. In the West of 63 positive identifications 40 were of adult sheep and 23 of lamb. Twenty-seven of these adult sheep occur-

Table 2

$\begin{aligned} & \text { The frequency of positive identifications } \\ & \text { of sheep and lamb remains in the } \\ & \text { stomachs of foxes from Lochaber and the } \\ & \text { West during April, May and June. }\end{aligned}$
$\begin{aligned} & \text { Lochaber } \\ & \text { West }\end{aligned}$
$\begin{array}{lcc}\text { Sheep } & 2 & 13 \\ \text { Lamb } & 18 & 23 \\ \text { \% lamb } & 90 & 64\end{array}$

rences were from the winter months. During the spring lamb remains predominated over sheep (Table 2). There was a higher proportion of lamb remains in the stomachs from Lochaber than from the West, although the difference was not significant (Table 2).

$$
\text { D. Deer }
$$

No attempt was made to distinguish between species of deer. In most cases a stomach full of deer remains had a large proportion of flesh 
and fat and identifications had often to be made on very few hairs. In a small number of stomachs there were large amounts of flesh but no hairs. While the general nature of these remains suggested that they may have come from deer they were recorded as unidentifiable and put in the "other vertebrate" category.

\section{E. Birds}

In most cases bird remains could be fairly easily assigned to order. There were marked differences between regions, Galliformes predominanting in the North-east, while Passeriformes occurred most frequently in the West and Lochaber (Table 3). There were distinctions between areas in the North-east in the actual species found. Of 15 identifiable Galliformes in areas 1 and 4, eight were of domestic

Table 3

Orders of birds found in the stomachs of foxes, expressed as a percentage of the number of stomachs in which bird remains occurred in each region

\begin{tabular}{lccc}
\hline Number of stomachs with birds & $\begin{array}{c}\text { North-east } \\
144\end{array}$ & $\begin{array}{c}\text { West } \\
19\end{array}$ & $\begin{array}{c}\text { Lochaber } \\
5\end{array}$ \\
\hline Galliformes & 43 & 5 & 20 \\
Columbiformes & 17 & 11 & - \\
Passeriformes & 13 & 21 & 60 \\
Anseriformes & 12 & 16 & - \\
Gruiformes & 4 & 5 & - \\
Charadriiformes & 1 & 16 & - \\
Unidentifiable & 15 & 32 & 20 \\
\hline
\end{tabular}

chicken, four of pheasant (Phasianus colchicus) and partridge (Perdix perdix), two of red grouse (Lagopus lagopus) and one of black grouse (Lyrurus tetrix). However in areas 2 and 3, of 23 identified species, 20 were red grouse, two domestic chickens and one pheasant. The identifiable Columbiformes were wood-pigeon (Columba palumbus). The most common passerine in the North-east was the blackbird (Turdus merula). Other species found in the West and Lochaber were the bullfinch (Pyrrhula pyrrhula) and the wheatear (Oenanthe oenanthe).

\section{F. Other Constituents}

The majority of insect remains were of medium size beetles which were not further identified. Fly maggots were occasionally found with sheep and deer remains, suggesting that they were ingested with carrion. On a few occasions there were quantities of caterpillars in a stomach. Earthworms were only found once. Vegetable remains were generally bits of grass bracken and various leaves, particularly fir 
needles. Most of these were brown and dead, suggesting that they had been ingested casually with other food items. Sometimes the amount of grass found suggested deliberate eating, and on one occasion rowan berries (Sorbus aucuparia) were found. Clover leaves and cereal grains were sometimes found in association with pigeons and ground birds and probably came from crop contents. Odd additional items consisted of fish and amhibian remains, and bits of mineral and human waste.

\subsection{Variation within Regions}

In order to see how the diet varied within regions the frequency of occurrence of food categories was compared between the areas in Fig. 1 , four in North-east Scotland and two in the West. There were no significant differences in the West. In the North-east there was some variation in the proportion of Lagomorph in the diet, from a low of $43 \%$ in area 1 up $62 \%$ in areas 2 and 3 . However these differences were small compared to those between regions. The diets of each sex in the North-east and West were also compared and no significant differences were found.

\subsection{Differences between Regions}

The diets of foxes in North-east and West Scotland were distinctly different in five categories of food (Fig. 2, Table 4). Lagomorph and bird

Table 4

The percentage frequency of occurrence of food items in the stomachs of adult foxes from two regions of Scotland over the whole year.

Probability $(p)$ from $2 \times 2$ contingency tables for comparisons of the number of stomachs with and without an item in one area with those and without in the other.

\begin{tabular}{|c|c|c|c|c|c|c|}
\hline & \multicolumn{3}{|c|}{$\%$ main item } & \multicolumn{3}{|c|}{$\%$ total items } \\
\hline & North-east & West & $p$ & North-east & West & $p$ \\
\hline Number of stomachs & 272 & 137 & & 272 & 137 & \\
\hline Lagomorph & 53 & 7 & .0001 & 62 & 14 & .0001 \\
\hline Microtus & 7 & 37 & .0001 & 14 & 62 & .0001 \\
\hline Other rodent & 3 & 2 & n.s. & 6 & 8 & n.s. \\
\hline Insectivore & 0 & 1 & n.s. & 2 & 4 & n.s. \\
\hline „Sheep' & 4 & 38 & .0001 & 7 & 45 & .0001 \\
\hline Deer & 3 & 10 & .01 & 4 & 13 & .001 \\
\hline Bird & 24 & 7 & .001 & 48 & 14 & .0001 \\
\hline Other vertebrate & 3 & 7 & n.s. & 5 & 7 & n.s. \\
\hline Insect & 0 & 0 & n.s. & 6 & 12 & n.s. \\
\hline Vegetable & 6 & 3 & n.s. & 24 & 24 & n.s. \\
\hline Remainder & 3 & 6 & n.s. & 5 & 1 & n.s. \\
\hline
\end{tabular}

remains were the most frequent items in stomachs in the North-east, and Microtus and "sheep " the most important in the West. There were also slightly more deer remains in the West as compared to the Northeast. 
An adequate sample of stomachs was available from Lochaber only in the spring and summer. When compared with foxes killed in the West for the same season there were some significant differences in the frequency of some stomach contents (Table 5). Fewer Microtus remains were present in the stomachs of the Lochaber sample, but more deer.

\subsection{Season Variation}

The most important items in the diet varied considerably in their occurrence in stomachs over the year (Fig. 2). In the North-east

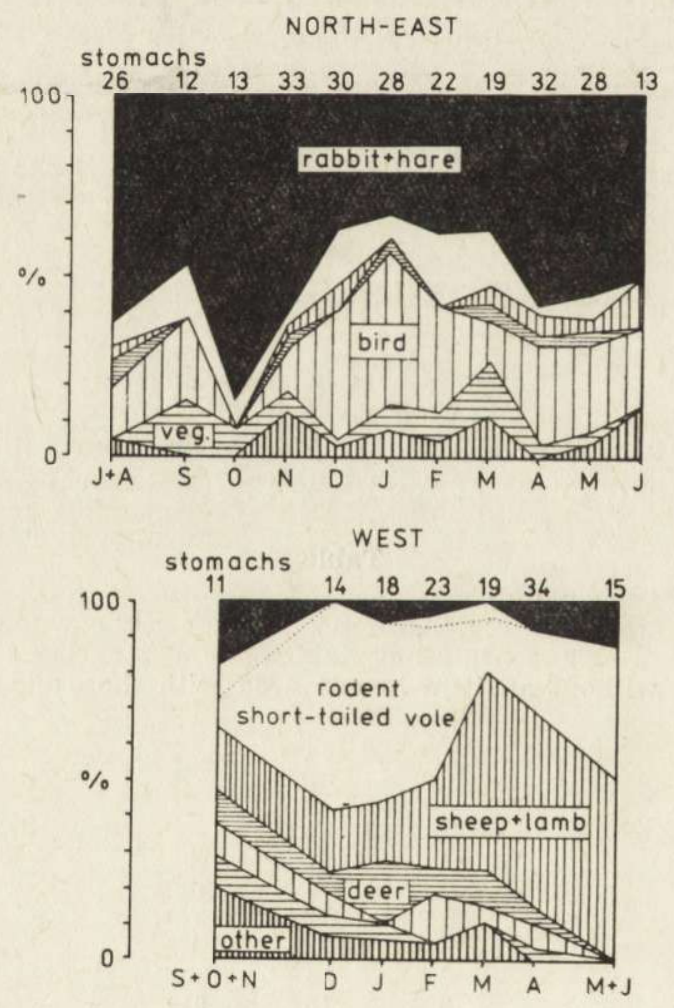

Fig. 2. The percentage relative frequency of the main items in the stomachs of foxes throughout the year in two regions of Scotland.

The number of stomachs in each sample is given above the months.

lagomorph occurred significantly more often as the main item in the autumn than in the winter and early spring, its place being taken by bird remains (Table 6). In the West Microtus was the main prey during the winter, but its place was taken by sheep and lamb during the spring (Table 5). 


\subsection{Differences between Years}

In the North-east the proportion of Lagomorph remains increased from 1972 to 1976 in stomachs and scats (Table 7). Microtus remains

Table 5

The percentage frequency of occurrence of food items in the stomachs of foxes killed in Lochaber and the West of Scotland from March to July.

\begin{tabular}{lrrrrrr}
\hline & \multicolumn{2}{c}{$\%$ main item } & \multicolumn{3}{c}{ \% total items } \\
& Lochaber & West & $p$ & Lochaber & West & $p$ \\
\hline Number of stomachs & 36 & 71 & & 36 & 71 & \\
Lagomorph & 6 & 7 & n.s. & 6 & 13 & n.s. \\
Microtus & 6 & 27 & .02 & 31 & 55 & .05 \\
Other rodents & 0 & 0 & n.s. & 0 & 7 & n.s. \\
Insectivore & 0 & 1 & n.s. & 6 & 6 & n.s. \\
Sheep' & 50 & 54 & n.s. & 56 & 62 & n.s. \\
Deer & 33 & 7 & .01 & 33 & 10 & .01 \\
Other vertebrate & 5 & 4 & n.s. & 8 & 6 & n.s. \\
Bird & 0 & 4 & n.s. & 11 & 13 & n.s. \\
Insect & 0 & 0 & n.s. & 17 & 18 & n.s. \\
Vegetable & 6 & 3 & n.s. & 31 & 20 & n.s. \\
Remainder & 0 & 0 & n.s. & 3 & 0 & n.s.
\end{tabular}

Table 6

Seasonal variation in the main item in fox stomachs from two regions of Scotland.

\begin{tabular}{lccc}
\hline & \multicolumn{3}{c}{ Months } \\
North-east & Sept.-Nov. Dec.-Mar. & $p$ \\
\hline Number of stomachs & 58 & 99 & \\
$\%$ lagomorph & 64 & 37 & .01 \\
$\%$ bird & 12 & 33 & .01 \\
\hline West & Dec.-Feb. & Mar.-July & \\
\hline Number of stomachs & 55 & 71 & \\
$\%$ Microtus & 56 & 27 & .01 \\
$\%$,sheep' & 22 & 54 & .001 \\
\hline
\end{tabular}

Table 7

The percentages of Lagomorph and Microtus remains as main items in stomachs and scats during the months October to April over five years north-east Scotland. For stomach contents the frequency of Microtus in 1971/2 is significantly different at $p=0.05$ from that in 1972/3. For scats frequencies of Microtus in $1972 / 3$ and $1975 / 6$ are significantly lower than for other years at $p=0.01$ For Lagomorph remains regression of $\%$ on year was significant for all 5 years for stomachs $(t=3.93, \alpha=0.02)$ and for last four years for scats $(t=4.26, \alpha=0.02)$.

\begin{tabular}{lcrccccc}
\hline Winter & \multicolumn{3}{c}{$\begin{array}{c}\text { Stomach contents } \\
\text { Lagomorph }\end{array}$} & Microtus & Sample size & Lagomorph & Scat contents \\
& Microtus & Sample size \\
\hline $1971 / 2$ & 33 & 25 & 12 & 65 & 28 & 54 \\
$1972 / 3$ & 47 & 2 & 47 & 63 & 15 & 27 \\
$1973 / 4$ & 46 & 8 & 26 & 63 & 23 & 60 \\
$1974 / 5$ & 51 & 9 & 59 & 70 & 19 & 311 \\
$1975 / 6$ & 55 & 4 & 29 & 75 & 4 & 165 \\
\hline
\end{tabular}


were also significantly more frequent in $1971 / 2$ than in $1972 / 3$ in both stomachs and scats and more frequent in 1973/4 and 1974/5 than in 1975/6 for scats (Table 7).

In the West there were significantly more Microtus in scats collected during the winters of $1971 / 2$ and $1974 / 5$ than in other years, and a greater proportion in stomachs in the spring of 1974 than in 1976 (Table 8). An annual index of vole populations was also obtained over these years from four lines of a hundred traps set in young forestry plantations (the positions of the trapping areas are shown in Fig. 1). These show a peak Microtus population in the autumn of 1974 .

Table 8

The percentage of Microtus remains as main item in stomachs and scats collected in successive years in West Scotland, and the number of Microtus caught in traps during the autumn.

Dashes indicate no sampling. For scat contents the frequencies are significantly greater in $1971 / 2$ and $1974 / 5$ than in other years at $p=0.01$. For stomachs the frequency in 1974 is significantly different from that in 1976 at $p=0.05$.

\begin{tabular}{|c|c|c|c|c|c|}
\hline \multirow[t]{2}{*}{ Winter/spring } & \multicolumn{2}{|c|}{$\begin{array}{l}\text { Scat contents } \\
\text { October-April }\end{array}$} & \multicolumn{2}{|c|}{$\begin{array}{l}\text { Stomach contents } \\
\text { March-June }\end{array}$} & \multirow{2}{*}{$\begin{array}{c}\text { Total number } \\
\text { of Microtus } \\
\text { caught in } 4 \\
\text { trap lines }\end{array}$} \\
\hline & Microtus & Sample size & Microtus & Sample size & \\
\hline $1971 / 2$ & 69 & 183 & - & - & - \\
\hline $1972 / 3$ & 51 & 166 & - & - & - \\
\hline $1973 / 4$ & 50 & 169 & 40 & 30 & - \\
\hline $1974 / 5$ & 69 & 408 & 26 & 23 & 112 \\
\hline $1975 / 6$ & 58 & 242 & 6 & 17 & 36 \\
\hline Autumn 1976 & - & - & - & - & 34 \\
\hline
\end{tabular}

\section{DISCUSSION}

\subsection{The Diet of Foxes in Different Parts of Scotland}

Using the results from this and other published studies the general pattern of the fox's diet in Scotland can be described. The main division is into East and West coast populations, the former eating mainly rabbits, game birds and poultry, and the latter voles, sheep and lambs, and in part deer. However within this broad division there are local variations in the proportion of different types of food taken, and, at the other extreme, it is not unreasonable to assume that there may be differences in the choice of food by different individuals.

On lowland agricultural and forested areas in the East the rabbit accounts for about half the annual food intake of foxes (Fig. 2). However the remainder of the diet consists of a wider range of species than in other parts of Scotland, mainly birds and rodents. Therefore, in theory at least, there will be a larger variety of alternative food 
sources should any one or a few of them vary in abundance. On the West however the range of foods taken is much more limited and this probably reflects a limited variety of prey. A single species, Microtus agrestis, accounts for more than half of the autumn and winter diet, while during the spring and summer sheep and lambs are the main source of food. Other items do not feature to a large extent in the diet, with the exception of deer which becomes more common in the Northwest, and is the main source of food in more remote Highland areas (L o c ki e, 1964).

In the country in between the foods taken depend upon the habitat. On grouse moors in the North-east mountain hares are the main food, with Red grouse next in importance. Towards the higher ground in the Cairngorms area deer are the chief item in the diet, whereas on the highest mountain areas voles are taken most frequently (W a tson, 1976).

In all these habitats the fox is adapting its diet to the abundance or ease of availability of food, whether it be prey or carrion, and with the exception of the higher ground of the Cairngorms, these are at high density due to, or as a by-product of human activities. The rabbit is generally present as a major agricultural pest. Mountain hares and Red grouse are encouraged by moor management. In the West high vole densities are promoted by extensive new afforestation, and in open hill areas most production goes into sheep farming and the maintenance of deer stocks for shooting.

\subsection{The Effect of the Fox on Agriculture}

In the North-east, purely from the point of view of agricultural production, it is arguable that the fox is beneficial. A large number of rabbits must be eaten every year to maintain foxes, although it is not known what impact this has on rabbit populations. Here the effect of foxes on sheep forming is negligible. The main depredation of foxes is considered to be on game birds, but overall these do not form a large proportion of the diet. The one game bird that appears in appreciable frequency is the Red grouse. However studies of the effect of predation on grouse populations suggest that the impact of foxes is mainly on surplus and dispersing grouse and that they have little effect. on the number available for shooting ( $\mathrm{J}$ enkins, Watson \& Mille r, 1964).

It seems reasonable to assume that most, if not all the adult sheep remains found in stomachs on the West, and particularly those found during the winter and spring, come from scavenged carcasses, just as most deer remains must do. In some cases there is direct evidence for 
this from the condition of the stomach contents and the presence of maggots and carrion beetles. Dead sheep are to be found throughout the year in hill areas with a peak in mortality just prior to lambing. However the main complaint against foxes is that they kill lambs, and it is clear that lamb remains were the most common item in foxes' stomachs from the West and Lochaber during the spring. In the West lambs accounted for about $35 \%$ of all the food eaten, whereas in Lochaber the figure was about $45 \%$. How many of these were killed and how many scavenged cannot be determined from stomach contents. Lockie (1964) in his study in Wester Ross found that the amount of lamb remains in scats at dens increased in a good lambing year in contrast to the number of lambs taken by eagles which went down. $\mathrm{He}$ suggested that eagles were therefore scavenging dead or unhealthy lambs in poor years, but did not draw the parallel conclusion that foxes may have been predating healthy lambs in the good lambing year. Clearly if the amount of lamb found in foxes' stomachs in the present study (a much larger proportion in the diet than found by Lockie further north) is an indication of actual predation then the fox presents a serious problem to hill farming in these areas. This question is being investigated by detailed studies of lamb mortality and fox behaviour.

\subsection{Variation in Prey Species}

To try to describe variation in prey densities from their proportion in the diet presents a number of problems, particularly if one is dealing with many species. Useful interpretations can only be made if there are large changes in the density of a main or a highly preferred species. Microtus populations fluctuate dramatically, often in unison over extensive areas ( $\mathrm{T}$ a p per, 1976). Laboratory tests have shown that foxes will select Microtus species to eat in preference to other rodents ( $\mathrm{L} u \mathrm{nd}, 1962$ ). Furthermore indices of populations are relatively easy to obtain by trapping. During the course of this study it seems clear that in the West of Scotland there were two main peaks in the vole population, in 1971 and 1974. 1971 was also a high vole year in the North-east, and populations may also have been higher than normal in 1973 and 1974, possibly indicating separate peaks in different parts of the area rather than one synchronous change. In North-east Scotland there has been a dramatic expansion of rabbit populations over the last few years. While this hås been clear to casual observers it has not been properly documented, but it seems to have been reflected in the increase in the proportion of lagomorph remains in the fox's diet.

These changes in prey populations have been correlated with a number of changes in the demography of fox populations in Scotland 
and these will be described in an ensuing paper ( $\mathrm{Hews}$ on \& $\mathrm{Kol}$ b, in prep.).

Acnowledgements: We would like to thank Dr. H. Kruuk and Mr. J. M. Todd for reading the munuscript and offering helpful suggestions for its improvement. We are especially grateful to all those in the Forestry Commission, and to all gamekeepers and shepherds who sent $\mathrm{s}$ fox carcasses, and in particular to $\mathrm{Mr}$. D Henderson for organising collection of foxes in the West. Part of the scat analysis work was financed by a grant from the Forestry Commission, and we would like to thank D. Cameron, P. Huggins, A.G. Knox and Miss K. Parr for their help in the collection and analysis of fox scats.

\section{REFERENCES}

1. Da y M.G., 1966: Identification of hair and feather remains in the gut and faeces of stoats and weasels. J. Zool., Lond., 148: 201-217.

2. Englund J., 1965: Studies on food ecology of the Red fox (Vulpes vulpes) in Sweden. Viltrevy, 3: $377-485$.

3. Hewson R. \& Kolb H.H., 1973: Changes in the numbers and distribution of foxes (Vulpes vulpes) killed in Scotland from 1948-1970 J. Zool., 171: 345-365 .

4. Jenkins D., Wats on A. \& Miller G.R., 1964: Predation and Red grouse populations. J. appl. Ecol., 1: 183-195.

5. L e ver R.J.A.W., 1959: The diet of the fox since myxomatosis. J. Anim. Ecol., 28: $359-375$.

6 Lockie J.D., 1956: After myxomatosis. Notes on the food of some predatory animals in Scotland. Scott. Agric., 36: 65-69.

7 Lockie J.D., 1959: The estimation of the food of foxes. J. Wildlife Manage, 23: $224-227$.

- 8. Lockie J.D., 1964: The breeding density of the Golden eagle and fox in relation to food supply in Wester Ross, Scotland. Scott. Nat., 71: 67-77.

9. Lund N.-K., 1962: The Red fox in Norway II. The feeding habits of the Red fox in Norway. Pap. Norweg. Game-Res. 2nd series, No 12: 1-79.

10. Southern H.N. \& W a ts on J.S., 1941: Summer food of the Red fox (Vulpes vulpes) in Great Britain: a preliminary report. J. Anim. Ecol., 10: $1-11$.

11. Tapper S.C., 1976: Population fluctuations of Field voles (Microtus): a background to the problems involved in predicting vole plagues. Mamm. Rev. 6: $93-117$

12. Watson A., 1970., (ed.): Animal populations in relation to their food resources. Blackwell: 1-477. Oxford.

13. W a ts on A., 1976: Food remains in the droppings of foxes (Vulpes vulpes) in the Cairngorms. J. Zool., Lond., 180: 495-496.

14. Wildman A.B., 1954: The microscopy of animal textile fibres. Wool Industries Research Association, Leeds.

Accepted, August 10, 1978. 


\section{APPENDIX I}

The percentage wet weight of ten food categories in the stomach contents of adult foxes, for the frequency data in Tables 4 and 5 .

\begin{tabular}{lcccc}
\hline & $\begin{array}{c}\text { North-east } \\
\text { Whole year }\end{array}$ & $\begin{array}{c}\text { West } \\
\text { Aug.-Feb. }\end{array}$ & $\begin{array}{c}\text { West } \\
\text { March-July } \\
\text { March-July }\end{array}$ & $\begin{array}{c}\text { Lochaber } \\
\text { March }\end{array}$ \\
\hline Weight of stomach contents: $\mathrm{Kg}$ & 24.35 & 4.14 & 10.35 & 6.12 \\
Lagomorph & 61.7 & 16.7 & 5.2 & 1.2 \\
Microtus & 3.5 & 31.2 & 18.7 & 10.1 \\
Small mammal & 1.7 & 0.2 & 2.1 & 0.5 \\
Sheep & 4.5 & 31.6 & 55.6 & 45.9 \\
Deer & 3.0 & 10.2 & 11.5 & 33.7 \\
Bird & 21.3 & 3.6 & 2.6 & 2.8 \\
Other vertebrate & 3.1 & 5.3 & 1.5 & 3.3 \\
Insect & 0.1 & 0.1 & 0.3 & 0.3 \\
Vegetable & 1.0 & 1.2 & 2.5 & 2.1 \\
Remainder & 0.1 & 0.1 & 0 & 0.1
\end{tabular}

\section{APPENDIX II}

The percentage dry weight of ten food categories in fox scats collected from October to April.

\begin{tabular}{|c|c|c|c|c|c|c|}
\hline & \multicolumn{3}{|c|}{ North-east } & \multicolumn{3}{|c|}{ West } \\
\hline & $73 / 4$ & $74 / 5$ & $75 / 6$ & $73 / 4$ & $74 / 5$ & $75 / 6$ \\
\hline Total weight g. & 565 & 2268 & 1138 & 1221 & 3611 & 2031 \\
\hline Lagomorph & 56.3 & 64.8 & 70.9 & 32.0 & 27.7 & 29.6 \\
\hline Microtus & 24.2 & 18.2 & 4.9 & 46.8 & 66.7 & 59.4 \\
\hline Small mammal & 5.1 & 1.3 & 1.5 & 3.5 & 0.6 & 0.2 \\
\hline Sheep & 0 & 0.3 & 2.2 & 4.7 & 1.8 & 4.0 \\
\hline Deer & 0 & 2.6 & 0.5 & 4.0 & 1.1 & 2.9 \\
\hline Bird & 11.9 & 6.0 & 11.1 & 7.4 & 0.7 & 0.8 \\
\hline Other vertabrate & 0.4 & 0 & 0 & 0.1 & 0 & 0.1 \\
\hline Insect & 0.6 & 0.1 & 0.7 & 0.9 & 0.1 & 0.5 \\
\hline Vegetable & 1.6 & 5.1 & 7.2 & 0.6 & 1.1 & 2.1 \\
\hline Remainder & 0 & 1.8 & 1.0 & 0.1 & 0.3 & 0.6 \\
\hline
\end{tabular}

\section{APPENDIX III}

Correlation coefficients $(r)$ between percentage wet weight (Appendix I) and percentage frequency of occurrence of stomach contents (Tables 4 and 5) for main and total occurrences, and the percentage of common variance accounted for by the correlation $\left(r^{2}\right)$.

\begin{tabular}{|c|c|c|c|c|c|}
\hline & & $\begin{array}{l}\% \text { wt. }- \\
\% \text { main item }\end{array}$ & $\begin{array}{l}\% \\
\text { var. }\end{array}$ & $\begin{array}{l}\% \text { wt. - } \\
\% \text { total items }\end{array}$ & $\begin{array}{c}\% \% \\
\text { var. }\end{array}$ \\
\hline \multicolumn{6}{|c|}{ Stomachs } \\
\hline North.-east. & ole year & 0.991 & & 0.893 & $\begin{array}{l}80 \\
54\end{array}$ \\
\hline $\begin{array}{l}\text { West. Aug.- } \\
\text { West. March }\end{array}$ & & 0.842 & 71 & $\begin{array}{l}0.732 \\
0.847\end{array}$ & 54 \\
\hline Lochaber & & $\begin{array}{l}0.980 \\
0.985\end{array}$ & $\begin{array}{l}96 \\
97\end{array}$ & $\begin{array}{l}0.847 \\
0.849\end{array}$ & $\begin{array}{l}72 \\
72\end{array}$ \\
\hline \multicolumn{6}{|c|}{ Scats } \\
\hline \multirow[t]{3}{*}{ North-east } & $1973 / 4$ & 0.990 & 98 & 0.938 & 88 \\
\hline & $1974 / 5$ & 0.999 & 100 & 0.956 & 91 \\
\hline & $1975 / 6$ & 0.996 & 99 & 0.936 & 88 \\
\hline \multirow[t]{3}{*}{ West } & $1973 / 4$ & 0.995 & 99 & 0.974 & 95 \\
\hline & $1974 / 5$ & 0.998 & 100 & 0.996 & 99 \\
\hline & $1975 / 6$ & 0.999 & 100 & 0.983 & 97 \\
\hline
\end{tabular}




\section{H. H. KOLB i R. HEWSON}

\section{ZRÓZNICOWANIE DIETY LISA W SZKOCJI}

\section{Streszczenie}

$\mathrm{Na}$ podstawie badań zawartości żołądków oraz badań kału stwierdzono różnice w diecie lisów (Vulpes vulpes Linnaeus, 1758) pochodzących z kilku rejonów Szkocji (Rys. 1). Podano listę gatunków drobnych ssaków znalezionych w żołądkach szkockich lisów (Tabela 1), stwierdzono zmienność geograficzną, sezonową oraz różnice między kolejnymi latami. Króliki oraz ptactwo łowne stanowią podstawowy pokarm lisa w północno-wschodniej Szkocji (Ryc. 2, Tabela 3). Jesienią i zimą norniki są głównym składnikiem pokarmu lisa w zachodniej Szkocji (Tabela 7), podczas gdy owce i jagnięta mają największy udział w pokarmie wiosennym (Tabele 2 i 6). W północno-zachodnich rejonach Szkocji zwierzyna płowa stanowi większy udział w pokarmie lisa (Tabela 4), natomiast występowanie norników i królików w diecie lisów uzależnione jest od fluktuacji liczebności populacji ofiar (Tabela 8). W zachodnich rejonach Szkocji wiosną szczątki jagniąt tworzą $35-45 \%$ diety lisa (Tabela 5), co przedyskutowano pod kątem zagęszczenia populacji lisów na terenach rolniczo zagospodarowanych. 